\title{
Effect of high dose inhaled beclomethasone dipropionate on carbohydrate and lipid metabolism in normal subjects
}

\author{
Y T KRUSZYNSKA, M GREENSTONE, P D HOME, N J COOKE \\ From the Department of Respiratory Medicine, Leeds General Infirmary, Great George Street, Leeds, and the \\ Freeman Diabetes Unit, Freeman Hospital, Newcastle upon Tyne
}

ABSTRACT The metabolic effects of four weeks' high dose inhaled beclomethasone dipropionate (500 $\mu \mathrm{g}$ twice daily) were studied in nine normal subjects with an open study design. No effect was found on fasting blood glucose concentration or glycosylated haemoglobin concentration. Peak blood glucose concentration 30 minutes after a $75 \mathrm{~g}$ oral glucose load was, however, significantly higher (7.1 (SEM 0.2) versus $6.7(0 \cdot 1) \mathrm{mmol} / \mathrm{l}$, or $128(3.6) v 121(1.8) \mathrm{mg} / 100 \mathrm{ml})$. After treatment there was a $36 \%$ increase in fasting serum insulin concentration $(7 \cdot 6(0 \cdot 7)$ versus $5.6(0.5) \mathrm{mU} / 1)$ and a $32 \%$ increase in the area under the serum insulin concentration curve after glucose challenge. High dose inhaled beclomethasone dipropionate treatment raised the fasting plasma cholesterol concentration $(4.62(0.25) \vee 4.16(0.26) \mathrm{mmol} / 1$, or $178(9.7) \vee 161(10.0) \mathrm{mg} / 100 \mathrm{ml})$ and high density lipoprotein cholesterol $(1 \cdot 19(0.065)$ versus $0.97(0.065) \mathrm{mmol} / \mathrm{l}$, or $45(2.5) v 37(2.5) \mathrm{mg} / 100 \mathrm{ml})$. Fasting blood lactate and pyruvate concentrations were also significantly higher and blood glycerol lower. The findings indicate that high dose inhaled beclomethasone dipropionate may disturb both carbohydrate and lipid metabolism.

High dose inhaled topically active corticosteroids are now in common use for the treatment of asthma. Although there is good evidence that standard doses of inhaled steroids (below $500 \mu \mathrm{g}$ daily of beclomethasone dipropionate) have no effect on blood glucose concentration or the hypothalamic pituitary-adrenal axis, ${ }^{12}$ little is known of the effects of higher doses of inhaled steroids on glucose and lipid metabolism. We have studied the effect of four weeks' treatment with inhaled beclomethasone dipropionate in a dose of $1000 \mu \mathrm{g} /$ day. This dose is now commonly used in clinical practice and has been shown not to cause adrenal suppression. ${ }^{34}$ The study was conducted in normal subjects, to avoid the confounding effect of other drugs used in asthma and known to affect lipid and carbohydrate metabolism.

\section{Methods}

Nine normal subjects (six male, three female) were recruited from among hospital and laboratory staff.

Address for reprint requests: Dr P D Home, Freeman Diabetes Unit, Freeman Hospital, Newcastle upon Tyne, NE7 7DN.

Accepted 3 June 1987
Their ages ranged from 21 to 44 years (mean 28 (SD 7) years), their weight from 47 to $80(67(10) \mathrm{kg}$ ), and their body mass index (BMI) from 21 to $25 \mathrm{~kg} / \mathrm{m}^{2}(23$ (2) $\mathrm{kg} / \mathrm{m}^{2}$ ). No subject had a family history of diabetes or was taking any medication. Approval for the study was given by the local ethical committee and informed consent was obtained in each case. Each subject was studied on two occasions four weeks apart, before and after aerosol treatment with beclomethasone dipropionate (Becloforte, Allen and Hanburys, Greenford, Middlesex) $500 \mu \mathrm{g}$ twice daily. The order of study was not randomised, to prevent hangover effects of the steroid treatment.

On each occasion subjects were admitted to the metabolic ward at $\mathbf{0 8 0 0}$ hours, having fasted from 2200 hours the previous evening. An intravenous cannula was inserted into an antecubital vein, and after a 30 minutes' rest period three basal blood samples were taken at 15 minute intervals for estimation of concentrations of glycosylated haemoglobin; serum insulin, blood glucose, and intermediary metabolites; and plasma cortisol, triglyceride, cholesterol, and high density lipoprotein cholesterol. At the start of the experiment subjects were given $75 \mathrm{~g}$ glucose in a volume of $390 \mathrm{ml}$, divided into five aliquots and given 

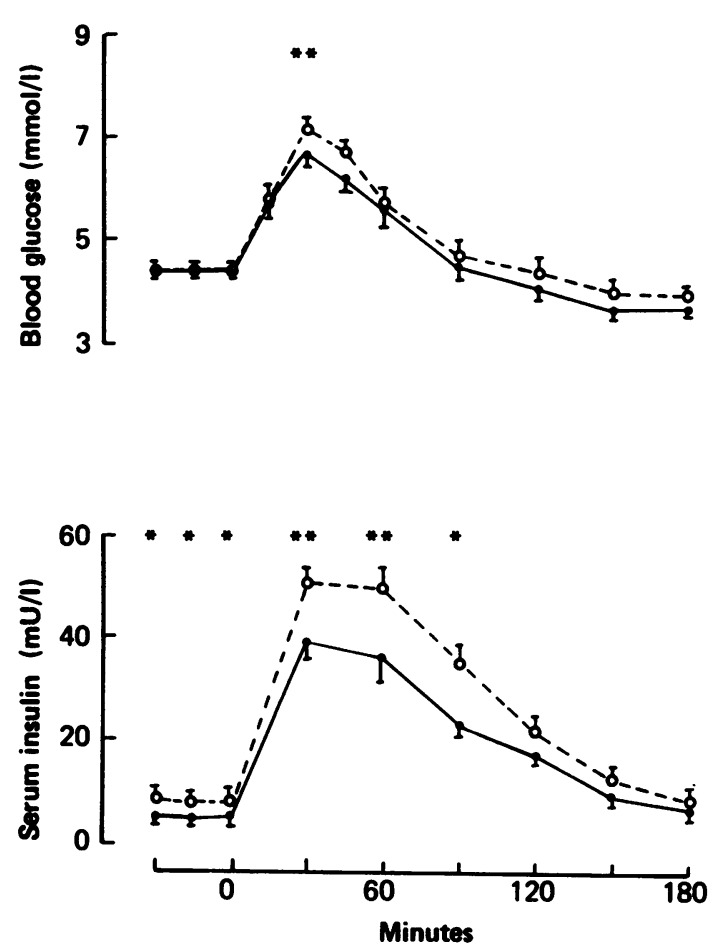

Blood glucose and serum insulin concentration in nine normal subjects before (•- $\bullet$ ) and after (0--- $)$ four weeks of inhaled beclomethasone dipropionate treatment ( $500 \mu \mathrm{g}$ twice daily). ${ }^{*} p<0.05 ;{ }^{* *} p<0.01$. Conversion: SI to traditional units-glucose: $1 \mathrm{mmol} / \mathrm{l}=18 \mathrm{mg} / 100 \mathrm{ml}$.

at minute intervals. Blood samples $(10 \mathrm{ml})$ for glucose and insulin estimation were taken at 30 minute intervals until 180 minutes from the start. After each sample the cannula was flushed with $0.15 \mathrm{~mol} / 1 \mathrm{NaCl}$ in water. Additional samples for glucose only were taken at 15 and 45 minutes.

Blood glucose was measured by a glucose oxidase method (Yellow Springs Glucose Analyser, Clandon Scientific, London) by the principal investigator. All other assays were performed by technicians unaware of the nature of the study. Blood for estimation of intermediary metabolites was immediately deproteinised with $0.6 \mathrm{~mol} / 1$ perchloric acid and the supernatant assayed by automated enzymic fluorimetric methods. ${ }^{5}$ Blood samples for lipid assay were collected in EDTA $(1 \mathrm{mg} / \mathrm{ml}$ of blood) and the plasma refrigerated immediately. Plasma cholesterol and triglyceride were measured by standard enzymatic methods (BCL Diagnostics, Lewes, Sussex). Plasma high density lipoprotein cholesterol was determined on samples of the supernatant after precipitation of apolipoprotein B containing lipoprotein particles with heparin manganese. ${ }^{6}$
Glycosylated haemoglobin was determined by $a n^{5}$ isoelectric focusing method. ${ }^{7}$ Serum insulin was mea $\frac{5}{0}$ sured by radioimmunoassay, ${ }^{8}$ with an interassats coefficient of variation of $7 \%$ in the physiologica range. Plasma cortisol was measured by a competitive protein binding technique. ${ }^{9}$

Results are expressed as means with standar errors in parentheses unless otherwise indicated. The significance of differences was tested by Student's. paired $t$ test. Correlations were sought by Pearson' least squares method. Areas under blood concen $x$ tration curves were calculated by the trapezoidal rulet.

\section{Results}

Plasma cortisol concentrations at $\mathbf{0 8 3 0}$ hours were not lower after four weeks' beclomethasone treatment (416 (30) versus 428 (42) nmol/1;. Body weight did not change with treatment. Fasting blood glucose concen? trations were identical before and after treatmen $\$$ (both $4 \cdot 4(0 \cdot 1) \mathrm{mmol} / \mathrm{l})$, but fasting serum insulin con centrations were significantly higher $(7.6(0.7) \vee 5.6$ $(0.5) \mathrm{mU} / 1 ; \mathrm{p}<0.05)$. After oral glucose blood gluxo cose concentration was higher only at 30 minutes $\left(7 \cdot \frac{1}{N}\right.$ $(0.2)$ versus $6.7(0.1) \mathrm{mmol} / 1$ (128 (4) $v 121$ (2) $\mathrm{mg} / 100 \mathrm{ml} ; \mathrm{p}<0.01$ ) (figure) and the areas under the incremental two hour curves did not differ $(11.0(0.4)$

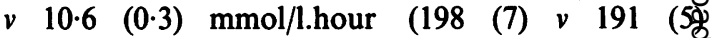
$\mathrm{mg} / 100 \mathrm{ml}$.hour)). Serum insulin concentrations were however, higher at 30,60 and 90 minutes (figure) with a $32 \%$ increase in the area under the concen

Fasting metabolic characteristics (means with standard errors in parentheses) before and after four weeks of inhalation of beclomethasone diproprionate ( $500 \mu \mathrm{g}$ twice daily) in nine normal subjects

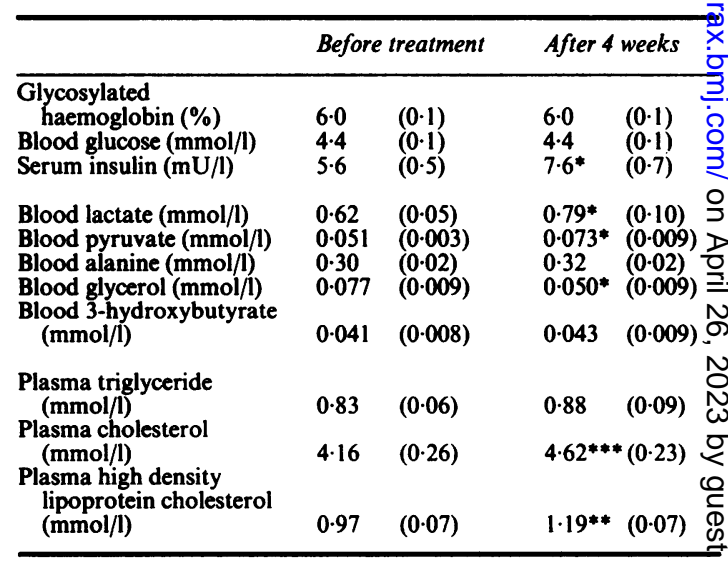

${ }^{*} \mathrm{p}<0.05 ;{ }^{* *} \mathrm{p}<0.01 ;{ }^{* * *} \mathrm{p}<0.001$

Conversion: SI to traditional units-Glucose: $1 \mathrm{mmol} / \mathrm{l}=18 \mathrm{mg} / 10 \mathrm{~A}$ $\mathrm{ml}$; lactate: $1 \mathrm{mmol} / \mathrm{l}=9.0 \mathrm{mg} / 100 \mathrm{ml}$; pyruvate: $1 \mathrm{mmol} / \mathrm{l}=8 \%$ $\mathrm{mg} / 100 \mathrm{ml}$; alanine: $1 \mathrm{mmol} / \mathrm{l}=8.9 \mathrm{mg} / 100 \mathrm{ml}$; glycerol: $1 \mathrm{mmol} / \mathrm{l} \oplus$ $9.2 \mathrm{mg} / 100 \mathrm{ml}$; 3-hydroxybutyrate: $1 \mathrm{mmol} / 1=10.4 \mathrm{mg} / 100 \mathrm{md}$ triglyceride: $1 \mathrm{mmol} / \mathrm{l}=88.5 \mathrm{mg} / 100 \mathrm{ml}$; cholesterol: $1 \mathrm{mmol} / \mathrm{l}$ o $38.6 \mathrm{mg} / 100 \mathrm{ml}$. 
tration curve (88 (8) $v 67$ (6) $\mathrm{mU} / 1$.hour; $\mathrm{p}<0.01)$. Glycosylated haemoglobin was not affected by treatment with inhaled beclomethasone (table).

Fasting blood lactate and pyruvate concentrations were increased $(p<0.05)$ by 27 and $43 \%$ respectively (table). Blood glycerol concentrations were decreased (table, p < 0.02). Blood alanine and 3-hydroxybutyrate concentrations, however, were unchanged.

Beclomethasone treatment had no effect on fasting plasma triglyceride concentration but was associated with a significant increase in both plasma cholesterol $(4.62(0.23) v 4.16(0.26) \mathrm{mmol} / \mathrm{l} 178(9) v 161(10)$ $\mathrm{mg} / 100 \mathrm{ml}) ; \mathrm{p}<0.001)$ and high density lipoprotein cholesterol $(1.19(0.07) v 0.97(0.07)(46$ (3) v 38 (3) $\mathrm{mg} / 100 \mathrm{ml}) \mathrm{mmol} / \mathrm{l} ; \mathrm{p}<0.01)$. Thus the total cholesterol:HDL-cholesterol ratio decreased from $4.4(0.4)$ to $4.0(0.3)(\mathrm{p}<0.05)$.

\section{Discussion}

In this study inhaled high dose beclomethasone had no major effect on glucose tolerance in normal subjects, but there were some metabolic changes. Serum insulin concentrations were increased both in the fasting state (table) and after oral glucose challenge (figure). In the absence of a change in blood glucose concentration this implies reduced sensitivity to insulin after beclomethasone treatment. As the main determinant of the fasting blood glucose concentration is the rate of hepatic glucose production, and as fasting blood glucose concentrations were identical despite a $36 \%$ increase in peripheral fasting insulin concentrations, it would seem likely that hepatic sensitivity to insulin is decreased. Increased blood lactate and pyruvate concentrations have been observed in several clinical conditions characterised by insulin insensitivity and hyperinsulinaemia, such as hepatic cirrhosis, ${ }^{10}$ non-insulin dependent diabetes, ${ }^{11}$ and Cushing's syndrome. ${ }^{12}$ The rise in blood lactate and pyruvate concentrations may therefore be a reflection of the hyperinsulinaemia induced by beclomethasone.

The degree of metabolic disturbance found in this study is rather less than that described in milder forms of Cushing's syndrome. ${ }^{12}$ Young women taking a mean of $10 \mathrm{mg}$ of prednisone or prednisolone orally showed changes in blood glucose responses, and the change in blood pyruvate concentrations were rather greater than those in the present study. ${ }^{13}$ Comparative data for serum lipid concentrations in healthy subjects taking steroids are not available.

Increased plasma cholesterol concentrations have been noted in patients with Cushing's syndrome and in patients taking oral corticosteroid preparations, in association with mild impairment of carbohydrate metabolism and hyperinsulinaemia as in the present study. ${ }^{14}$ The enhanced hepatic cholesterol synthesis induced by corticosteroids may be secondary to a rise in insulin secretion as insulin is a major regulator of the rate limiting enzyme for cholesterol synthesis in the liver. ${ }^{15}$ Furthermore, glucocorticoids are known to have enhancing effects on some aspects of insulin action in the liver. ${ }^{16}$ Although the increase in serum cholesterol concentration was small $(4.62(0.23) v 4 \cdot 16$ $(0.26) \mathrm{mmol} / \mathrm{l} ; \mathrm{p}<0.001)$ it was consistent and was seen in all subjects studied. Small increments in plasma cholesterol concentration within the accepted normal range are associated with a substantial increase in cardiovascular risk, ${ }^{17}$ and there may be an association between hyperinsulinaemia and major vessel disease. ${ }^{18}$ High density lipoprotein cholesterol concentrations, however, also rose in our study, causing a small fall in the ratio of total to high density lipoprotein cholesterol, and this change would be expected to mitigate the effects of the rise in total cholesterol concentrations. Our findings suggest the need for further studies of the metabolic effects of long term beclomethasone treatment.

The amount of beclomethasone absorbed by the subjects in this study, as in previous studies, ${ }^{34}$ caused metabolic changes in the absence of any change in plasma cortisol concentrations, reflecting the different dose-response relationships for these different actions of corticosteroids.

The subjects studied here were relatively young. Possibly the effects of beclomethasone on glucose and lipid metabolism are different in the older individual or the patient with a predisposition to diabetes in whom sensitivity to insulin is already diminished. While inhaled glucocorticoids have greatly reduced the morbidity of chronic severe asthma, often allowing a reduction in oral steroid dosage, ${ }^{4}$ continuing surveillance of the long term consequences of such treatment appears to be indicated.

We thank Allen and Hanburys for the supply of beclomethasone dipropionate inhalers, Ms L Ashworth for metabolite assays, and the British Diabetic Association for financial support.

\section{References}

1 Goldstein DE, Konig P. Effect of inhaled beclomethasone dipropionate on hypothalamicpituitary-adrenal axis function in children with asthma. Pediatrics 1983;72:60-4.

2 Yernault JC, Leclercq R, Schanderyl W, Virasoro E, De Coster A, Copinschi G. The endocrinometabolic effects of beclomethasone dipropionate in asthmatic patients. Chest 1977;71:698-702.

3 Gaddie J, Reid IW, Skinner C, Petrie GR, Sinclair DJM, Palmer KNV. Aerosol beclomethasone dipropionate: a dose-response study in chronic bronchial asthma. Lancet 1973;ii:280-1. 
4 Smith MJ, Hodson ME. Effects of long term inhaled high dose beclomethasone dipropionate on adrenal function. Thorax 1983;38:676-81.

5 Lloyd B, Burrin J, Smythe P, Alberti KGMM. Simple automated fluorimetric assays for blood glucose, lactate, pyruvate, alanine, glycerol and 3-hydroxybutyrate. Clin Chem 1978;24:1724-9.

6 Warnick GR, Albers JJ. A comprehensive evaluation of the heparin-manganese precipitation procedure for estimating high density lipoprotein cholesterol. J Lipid Res 1978;19:65-76.

7 Strickland MH, Perkins CM, Wales JK. The measurement of haemoglobin $A_{1}$ by isoelectric focussing in diabetic patients. Diabetologia 1982;22:315-7.

8 Soeldner JS, Sloane D. Critical variables in the radioimmunoassay of serum insulin using the doubleantibody technic. Diabetes 1965;11:541-8.

9 Baum CK, Tudor R, Landon J. A simple competitive protein binding assay for plasma cortisol. Clin Chem Acta 1974;55:147-54.

10 Johnston DG, Alberti KGMM, Binder C, Faber OK, Wright R, Orskov H. Hormonal and metabolic changes in hepatic cirrhosis. Horm Metab Res 1982;14:34-9.

11 Nattrass M, Alberti KGMM. Lactate metabolism in diabetes. In: Bossart $\mathrm{H}$, Perret $\mathrm{C}$, eds. Lactate in acute conditions. Basel: Karger, 1979:83-101.

12 Johnston DG, Alberti KGMM, Nattrass M, Barnes AF Bloom SR, Joplin GF. Hormonal and metabolis rhythms in Cushing's syndrome. Metabolis 1980;29:1046-52.

13 Doar JWH, Wynn V. Effect of obesity, glucocorticoid? and oral contraceptive therapy on plasma glucose and blood pyruvate levels. Br Med J 1970;i:149-52.

14 Havel RJ, Goldstein JL, Brown MS. Lipoproteins and lipid transport. In: Bondy PK, Rosenberg LE, ed Metabolic control and disease. 8th ed. Philadelphi WB Saunders, 1980:393-485.

15 Ingebritsen TS, Geelen MJH, Parker RA, Evenson KA Gibson DM. Modulation of hydroxymethylglutaryCoA reductose activity, and cholesterol synthesis izo rat hepatocytes in response to insulin and glucagon. 9 Biol Chem 1979;254:9986-9.

16 Gelehrter TD. Synergistic and antagonistic effects of glư cocorticoids on insulin action. In: Baxter JD, Rousseau GG, eds. Glucocorticoid hormone action. Berlireb Springer-Verlag, 1979:583-91.

17 Rose G, Shipley M. Plasma cholesterol concentrations and death from coronary heart disease: 10 year resul of the Whitehall study. $\mathrm{Br} \mathrm{Med} J$ 1986;293:306-7.

18 Stout RW. Diabetes and atherosclerosis-the role of insulin. Diabetologia 1979;16:141-50. 